\title{
A new insight into FEIA
}

\author{
Jennifer Yan Fei Chen ${ }^{1}$, Jason Kihyuk Lee ${ }^{2^{*}}$ \\ From Canadian Society of Allergy and Clinical Immunology Annual Scientific Meeting 2011 \\ Quebec, Canada. 20-23 October 2011
}

Two cases of patients with food and exercise-induced anaphylaxis (FEIA) with confirmed allergies to oral allergy syndrome are herein presented. Patient A had food anaphylaxis to fresh coriander and tomato and Patient $\mathrm{B}$ to fresh celery. These food allergens have structural antigenic similarity to that of birch and/or grass. Both patients' allergies were confirmed by fresh prick-to-prick tests. In both cases, strenuous exercise before the reaction was the only cofactor and the patients had absolutely no symptoms with the offending foods outside of exercise. The exercise had likely lowered the threshold for their reactions. The current literature propose that in FEIA, there is increased GI permeability, leading to enhanced allergen absorption [1]. However, van Nieuvenhoven et al found that intestinal permeability actually decreases with exercise [2]. In fact, Bi and Triadafilopoulos noted in their review that strenuous exercise delays gastric emptying of liquids and solids and inhibits gastric acid production [3]. These studies have led us to propose of a novel paradigm for the mechanism of FEIA. The general inhibitory effects of exercise on the GI tract decrease the digestion of oral allergens, thus leaving the allergens more structurally intact and thereby allowing continued systemic absorption of the allergen. This mechanism is supported by Untersmayr and Jensen-Jarolim's findings on the increased risk of labile food allergy induction with the use of antacid medications [4]. We propose the decrease in gastric acid in exercise as a more biologically plausible hypothesis of the mechanism of FEIA to oral allergens foods.

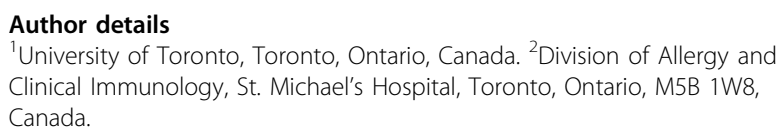

Published: 14 November 2011

${ }^{2}$ Division of Allergy and Clinical Immunology, St. Michael's Hospital, Toronto, Ontario, M5B 1W8, Canada

Full list of author information is available at the end of the article

\section{References}

1. Robson-Ansley P, Toit GD: Pathophysiology, diagnosis and management of exercise-induced anaphylaxis. Current opinion in allergy and clinical immunology 2010, 10(4):312-317.

2. van Nieuwenhoven MA, Brouns F, Brummer RJ: Gastrointestinal profile of symptomatic athletes at rest and during physical exercise. European journal of applied physiology 2004, 91(4):429-434.

3. Bi L, Triadafilopoulos G: Exercise and gastrointestinal function and disease: an evidence-based review of risks and benefits. Clin Gastroenterol Hepatol 2003, 1:345-55.

4. Untersmayr $E$, Jensen-Jarolim $E$ : The role of protein digestibility and antacids on food allergy outcomes. The Journal of allergy and clinical immunology 2008, 121(6):1301-1308, quiz 1309-1310.

doi:10.1186/1710-1492-7-S2-A32

Cite this article as: Yan Fei Chen and Kihyuk Lee: A new insight into FEIA. Allergy, Asthma \& Clinical Immunology 2011 7(Suppl 2):A32.
Submit your next manuscript to BioMed Central and take full advantage of:

- Convenient online submission

- Thorough peer review

- No space constraints or color figure charges

- Immediate publication on acceptance

- Inclusion in PubMed, CAS, Scopus and Google Scholar

- Research which is freely available for redistribution
() Biomed Central

reproduction in any medium, provided the original work is properly cited. 